\title{
Pendidikan Kesehatan pada Ibu Hamil dan Nifas tentang Asi Ekslusif untuk Meningkatkan Cakupan Asi Ekslusif
}

\author{
Winda Nurmayani ${ }^{1}$, Syamdarniati $^{2}$, Misroh Mulianingsih ${ }^{3}$, Indah Wasliah ${ }^{4}$, Sopian Halid $^{5}$ \\ $1,2,3,4,5$ STIKES Yarsi Mataram \\ *Email: nurmayani.winda81@ gmail.com
}

\begin{abstract}
Background: The Indonesian government has targeted exclusive breastfeeding $80 \%$, but exclusive breastfeeding is not widely done, although the benefits of exclusive breastfeeding are very many, especially for babies and mothers, but in fact many mothers do not give exclusive breastfeeding to their babies, and in the field many mothers stop giving Breast milk in her baby before the age of 2 years. The process of early breastfeeding does not always run smoothly, sometimes mothers and babies experience various obstacles that hinder or complicate the process of breastfeeding, especially if this is the first experience for primigravida mothers who are still young and have a low level of knowledge about breastfeeding that hinders the practice of breastfeeding, and usually her child is not yet 2 years old ASI has been discontinued (Dewanetal., 2002; Yanikkeremetal., 2009). The purpose of this community service is to educate pregnant and post-partum mothers how to properly care for breast and breastfeeding techniques in an effort to increase exclusive breastfeeding coverage. Methods: This community service method is carried out by means of counseling in delivering material then followed by demonstrations and Q\&A sessions. Results: The results of this dedication appear to be still many pregnant women and postpartum mothers who do not know the benefits of exclusive breastfeeding, how to care for the breast and how to breastfeed the right baby techniques, after health promotion and demonstration it appears that pregnant women and postpartum mothers are serious in understanding every step demonstrated. . Conclusion: Based on the results of the service, it is hoped that this activity can increase the coverage of breastfeeding mothers so that they can provide exclusive breastfeeding to their babies.
\end{abstract}

Keywords: breast care, breastfeeding techniques, breast milk

\section{PENDAHULUAN}

Secara Global WHO dan UNICEP telah mengimbau pemberian ASI Eksklusif, hal ini terlihat dari pertemuan sejak 1999 dan menjadikannya sebagai aksi global dengan isi deklarasi yang menyangkut kerjasama dalam perlindungan, promosi dan dukungan. Menuju program pemberian Asi Eksklusif dan menyerukan agar kebijakan tersebut ditindak lanjuti oleh semua negara yang ada di dunia (Aarts et al., 2000).

Pemerintah Indonesia telah menargetkan $80 \%$ pemberian ASI Eksklusif, sesuai dengan PP Nomor 33 Tahun 2012 tentang Pemberian ASI Eksklusif yang telah diperbaharui namun kenyataan di lapangan tidak semua ibu-ibu memberikan ASI pada bayinya, meskipun manfaatnya sangat banyak buat ibu dan bayi tetapi masih banyak ibu-ibu memberhentikan menyusui sebelum usia anaknya 2 tahun (Dewan et al., 2002);(Yanikkerem et al., 2009).

Dari hasil penelitian bahwa manfaat ASI, bagi kelangsungan hidup anak telah terbukti, namun terdapat beberapa faktor yang mempengaruhi pelaksanaan praktik menyusui, diantaranya ibu tidak menyusui karena ASI belum keluar, paritas, operasi caesar, kurangnya dukungan dari penolong persalinan, pemberian susu formula terlalu cepat, belum dilaksanakannya inisiasi menyusu dini dan banyak ibu yang tidak tahu manfaat Air Susu Ibu serta bagaimana merawatnya, untuk mempercepat 
produksi ASI sehingga pemberian ASI tidak berkelanjutan sampai bayi berusia 2 tahun (Mulyani, 2013). Di sisi lain, promosi susu formula yang tidak terkontrol dapat mengubah keputusan ibu untuk menyusui sendiri dan dapat menghambat proses laktasi sehingga bayi segera diberikan pengganti ASI. Hasil penelitian menemukan bahwa 25\% anak di Brazil mendapat air dan teh herbal, dan 22\% diberi susu formula pada bulan pertama kehidupannya. Hasil penelitian di Korea Utara, pelaksanaan promosi susu formula tidak berjalan dengan baik, karena hingga tahun 2006 hanya 1,8\% yaitu 57 dari 3.126 fasilitas penitipan ibu dan anak yang mendapat akreditasi sayang bayi (Chung, Kim and Nam, 2008).

Untuk meningkatkan cakupan pemberian ASI Eksklusif, produksi ASI harus lancar dengan cara melakukan; perawatan; payudara; atau breast; care; dengan tujuan peredaran darah menjadi lancar serta dapat mencegah saluran produksi ASI tersumbat dan pada akhirnya pengeluaran ASI menjadi lancar (Kristiyansari, 2009). Perawatan payudara merangsang hipofisis untuk melepaskan hormon prolaktin dan oksotisin untuk memproduksi dan mengeluarkan ASI. Prolaktin juga dipengaruhi oleh gizi ibu, sehingga semakin bagus kualitas gizi ibu maka produksi ASI yang dihasilkan juga meningkat (Agustina, 2014).

Menurut penelitian Mulianingsih, Nurmayani and Rusiana, (2016) terdapat pengaruh yang signifikan pendidikan kesehatan bagi ibu yang diberikan penyuluhan daripada ibu yang hanya diberikan; leaflet; terhadap; onset; laktasi; pada ibu yang sudah post SC, artinya bahwa akan ada perubahan perilaku ibu-ibu yang diberikan pendidikan kesehatan dengan metode penyuluhan.

Kondisi masyarakat di wilayah yang menjadi basis pengabdian masyarakat sebagian besar merupakan masyarakat dengan kondisi sosial ekonomi rendah, hal ini nampak dari ketidakpastian pendapatan masyarakat dari hasil pertanian dan pedagang dan peternakan sebagian besar berprofesi sebagai buruh. Untuk Pendidikan Banyak masyarakat yang masih tidak melanjutkan pendidikan karena berbagai alasan, salah satunya adalah alasan ekonomi.

Sebagian besar belum mengetahui konsep manfaat ASI eksklusif. Salah satu solusi strategis yang ditawarkan dalam kegiatan pengabdian ini adalah meningkatkan pengetahuan masyarakat tentang ASI Eksklusif. Tujuannya untuk meningkatkan pengetahuan peserta dalam perawatan payudara dan teknik menyusui sehingga meningkatkan cakupan asi ekslusif. Manfaat kegiatan ini bagi ibu hamil adalah untuk mempersiapkan diri agar produksi ASI lancar dan bagi ibu nifas bermanfaat untuk mendorong agar ibu dapat menyusui anaknya hingga 6 bulan. Manfaat kegiatan ini secara umum adalah meningkatkan angka keberhasilan pemberian ASI ekslusif di Lombok Barat.

\section{TINJAUAN PUSTAKA}

\subsection{Pengertian ASI Eksklusif}

Asi ekslusif adalah pemberian ASI saja pada bayi tanpa makanan atau cairan lain kecuali obat sampai usia 6 bulan(Haryono and Setianingsih, 2014). 


\subsection{Manfaat Pemberian Air Susu Ibu (ASI)}

Adapun manfaat Bagi Bayi menurut Depkes, RI, (2001)

a. Aspek Gizi : Kolostrum membantu melancarkan pengeluaran feses bayi (mekonium).

b. Aspek Imunologi (Kekebalan Tubuh)

c. Aspek psikologi

d. Aspek kecerdasan

e. Aspek Neurologis

Bagi ibu antara lain:

a. Mengurangi terjadinya perdarahan dan anemia

b. Menunda kehamilan

c. Mengecilkan Rahim

d. Menurunkan berat badan ibu

e. Meningkatkan imunitas tubuh ibu sehingga dapat mengurangi resiko terkena kanker payudara.

\subsection{Jenis ASI}

a. Kolostrum

Ini adalah cairan pertama yang keluar, berwarna kekuningan. Mengandung banyak protein, leukosit, vitamin A dan antibodi (imunitas). Keluar di hari pertama hingga hari ketiga

b. Masa Transisi Susus Air

Transisi Asi dari kolostrum ke Asi Matur. Keluar 4-10 hari

c. Susu matang

Cairan putih kekuningan. Berisi semua nutrisi, hari ke-10 dan seterusnya (Haryono dan Setianingsih, 2014)

\subsection{Perawatan Payudara}

Perawatan ini dilakukan 6 minggu terakhir kehamilan. Dengan pemijatan ini diharapkan ASI bisa keluar dengan lancar. Waktu pelaksanaan antara lain

a. Masa Kehamilan (antenatal)

Perawatan payudara dimulai pada usia kehamilan enam bulan. Memperhatikan nutrisi, ibu makan dengan porsi lebih banyak dari sebelum hamil. Membuat ibu tetap bahagia dengan kehamilannya.

b. Setelah Melahirkan (prenatal)

Mengajarkan ibu bagaimana teknik menyusui yang benar setelah melahirkan dimulai dari 30 menit pertama, ibu dibantu posisi menyusui sehingga perlekatan bayi sempurna,Membantu kontak langsung antara bayiibu 24 jam sehari agar pemberian ASI dapat dilakukan tanpa jadwal. - Ibu nifas diberikan kapsul vitamin A dosis tinggi (200.000S1) dalam waktu dua minggu setelah nifas. 
c. Masa Menyusui berikutnya (pasca melahirkan)

Menyusui bayi sampai usia 6 bulan tanpa makanan atau minuman lain kecuali obat (ekslusif). Porsi makanan dan gizi pada ibu juga harus di perhatikan, seperti porsi makan lebih banyak 1,5 kali dari biasanya, begitupun dengan minum, ibu menyusui harus berusaha menghabiskan minimal delapan gelas dalam sehari. Rasa lelah yang berlebihan akan berisiko terhambatnya ASI, oleh karena itu ibu menyusui dianjurkan untuk agar istirahat yang cukup dan pikiran selalu tenang. Untuk menunjang keberhasilan pemberian ASI diperlukan dukungan dari keluarga selama proses menyusui. Melakukan rujukan ke pelayanan keehatan terdekat jika terjadi masalah pada waktu menyusui seperti payudara bengkak, demam pada ibu. Pemberian makanan pendamping ASI harus cukup pada usia diatas 6 bulan.

\subsection{Prosedur Menyusui yang Sesuai}

a. Persiapan sebelum Menyusui

1) Pembentukan dan persiapan ASI

Saat hamil, payudara membesar karena retensi air, lemak, dan perkembangan kelenjar payudara yang terasa tegang dan perih.

2) Persiapan peluncuran ASI:

Membersihkan puting susu dengan minyak kelapa atau air hangat, agar kotoran yang menempel di puting keluar, puting yang masuk bisa dilepas dengan cara menariknya setelah mandi, atau bisa ditarik menggunakan pompa susu.

3) Posisi ibu dalam menyusui

Ada beberapa posisi ibu dalam menyusui seperti duduk, berdiri dan berbaring (Haryono dan Setianingsih, 2014).

b. Teknik Menyusui dengan Benar

Teknik menyusui yang benar adalah cara memberikan ASI pada bayi dengan pelekatan ibu dan bayi dengan baik.

Beberapa Teknik Menyusui:

1) Cuci tangan Anda dengan sabun dan air mengalir

2) Keluarkan sedikit ASI dan oleskan pada papila dan aerola mamae

3) Duduk dan berbaring dengan nyaman, jika duduk jangan gantung kaki Anda dan cobalah untuk menyandarkan bahu ke belakang.

4) Bayi diletakkan berhadap-hadapan dengan ibu dengan posisi menopang seluruh tubuh bayi. Perut ibu dan bayi menempel

5) Kepala dan badan bayi tegak

6) Sentuhkan bibir bayi ke puting susu, hingga mulut bayi terbuka lebar

7) Letakkan puting susu di dalam mulut bayi hingga sebagian besar areola berada di dalam mulut bayi.

8) Cara melepaskan isapan bayi: jari kelingking ibu dimasukkan ke dalam mulut bayi melalui sudut mulut, atau dagu bayi ditekan ke bawah. 
9) Pemberian ASI berikutnya dimulai dari payudara yang belum dikosongkan (Haryono and Setianingsih, 2014).

c. Jenis Posisi Menyusui

1) Bersandar

2) Cradle hold (menekuk satu tangan untuk menopang bayi)

3) Cross Cradle Hold (sama seperti cradle hanya dengan posisi tangan berhadapan dengan payudara tempat bayi menyusu

4) Berbaring (side lying)

5) Foot Ball Hold (menggendong bayi di satu sisi, tepatnya di bawah lengan

6) Duduk bayi (sitting baby)

d. Durasi Menyusui

Memberikan ASI on demand atau tanpa jadwal adalah cara terbaik karena dapat mencegah masalah pada proses menyusui dan bayi tetap kenyang. Semakin sering disusui berpengaruh terhadap penambahan berat badan bayi, bayi akan mendapatkan gizi yang optimal. Semakin lama bayi menyusu, maka bayi menerima asupan foremilk dan hindmilk secara seimbang (WHO, 2011).

\section{METODE}

Iiptek untuk masyarakat ini dilaksanakan pada hari kamis, 6 Februari 2020 mulai pukul 08.00 sampai dengan selesai, di Balai Dusun Bajur Kelurahan Bajur, sasaran dalam promosi kesehatan ini adalah ibu hamil dan nifas. Observasi lapangan dilakukan melalui koordinasi dengan kepala lingkungan dan kader kesehatan Dusun Bajur untuk menginformasikan dan menghimbau para ibu nifas dan ibu menyusui untuk dapat mengikuti kegiatan ini.

Adapun metode kegiatan ini adalah

a. Pre tes

Mengukur pengetahuan awal peserta tentang perawatan payudara dan teknik menyusui menggunaan kuisioner

b. Melakukan promosi kesehatan, melakukan demonstrasi serta pendampingan langsung cara perawatan payudara dan teknik menyusui

c. Post Tes

Mengukur kembali pengetahuan peserta tentang perawatan payudara dan teknik menyusui menggunaan kuisioner yang sama

Hasil pre dan post tes kemudian di analisa menggunakan Paired T-tes menggunakan SPS edisi 16

\section{HASIL}

Berdasarkan pantauan kami selaku tim pelaksana kegiatan pengabdian masyarakat ini, kami melihat bahwa antusiasme ibu hamil dan ibu nifas sangat tinggi, dimana banyak ibu-ibu yang hadir, terdiri dari ibu hamil dan nifas yang mengikuti kegiatan, serta ibu hamil dan ibu nifas sangat serius mengikuti kegiatan dari awal hingga akhir, diskusi berlanjut dengan sistem dua arah. 
Saat pembicara mereview tentang pengetahuan ibu hamil dan ibu yang membahas tentang manfaat ASI Eksklusif, cara merawat payudara, teknik posisi menyusui yang benar, banyak ibu hamil dan nifas yang masih belum paham tentang ASI Eksklusif, langkah-langkah dalam merawat payudara. dan cara memposisikan teknik menyusui yang benar, sebagai berikut :

a. Saat pemateri memberikan penyuluhan tentang ASI Eksklusif, cara merawat payudara dan teknik menyusui yang benar, peserta sangat antusias, beberapa ibu bertanya.

b. Pada saat peragaan cara merawat payudara dan peragaan cara menyusui dengan teknik yang benar, peserta memperhatikan setiap langkah dengan seksama, dan pada sesi tanya jawab beberapa ibu nifas mengajukan pertanyaan terkait yang kurang mereka pahami.

c. Menjelang acara hampir selesai pemateri memberikan beberapa pertanyaan tentang materi tentang ASI Eksklusif, langkah-langkah dalam merawat payudara dan teknik menyusui yang benar sebagai bahan evaluasi, serta respon yang diterima dari ibu hamil dan nifas sangat baik, peserta mengisi kuisioner yang telah dibagikan. Salah satu peserta memperagakan teknik menyusui dan cara merawat payudara

Tabel dibawah ini akan menggambarkan pengetahuan peserta sebelum dan setelah diberikan promosi kesehatan

Tabel 1. Menilai Pengetahuan Ibu Nifas dalam Merawat Payudaranya Sebelum dan Setelah dilakukan Promosi Kesehatan di Kelurahan Bajur Tahun 2020

\begin{tabular}{|c|c|c|c|c|c|}
\hline \multirow{2}{*}{$\begin{array}{l}\text { Pengetahuan Ibu } \\
\text { Sebelum dan Sesudah } \\
\text { dilakukan Promkes } \\
\end{array}$} & \multicolumn{3}{|c|}{ Nilai Pengetahuan } & \multirow{2}{*}{ Total } & \multirow{2}{*}{$\begin{array}{c}\text { Paired } \\
\text { T-tes }\end{array}$} \\
\hline & Rendah & Sedang & Tinggi & & \\
\hline Sebelum & 18 & 6 & 5 & 29 & $0,035 \%$ \\
\hline Setelah & 5 & 5 & 19 & 29 & \\
\hline
\end{tabular}

Berdasarkan tabel 1 hasil Pre tes pengetahuan ibu nifas tentang cara merawat payudara dan tekni menyusui 18 orang peserta pengetahuan rendah, 6 peserta pengetahun sedang, 5 orang peserta pengetahuan tinggi. Setelah diberikan promosi kesehatan peserta yang pengetahuan tinggi 19, pengetahuan sedang dan rendah masing-masing 5 orang. Didapatkan nilai paired t-tes 0,035 , menunjukkan pengetahuan peserta sebelum dan setelah kegiatan promosi kesehatan sebanyak $35 \%$ dalam merawat payudaranya. Pada saat melakukan demontrasi cara merawat payudara dan teknik menyusui yang benar, para peserta sangat seksama dalam memperhatikan langkah-langkahnya. Saat sesi tanya jawab beberapa ibu hamil dan ibu nifas mengajukan pertanyaan terkait perawatan payudara contoh pertanyaan, merawat payudara apakah perlu dan apa manfaatnya, berapa kali sehari melakukan perawatan payudara, dan ddidapatkan hasil $95 \%$ memahami cara perawatan payudara.

Hasil pengolahan data nilai pre tes dan post tes menunjukkan adanya peningkatan pengetahuan setelah dilakukan promosi kesehatan. Hal ini terlihat dari peningkatan nilai pengetahuan yang awalnya hanya 5 orang pengetahuan tinggi 
berubah menjadi 19 orang berpengetahuan tinggi. Penulis dan peserta sangat berharap ada kegiatan edukasi kesehatan ibu dan anak berkala dari Puskesmas atau pihak terkait, untuk mendukung program daerah maupun pemerintah dalam meningkatkan derajat kesehatan.

\section{PEMBAHASAN}

Pemberian ASI Eksklusif pada bayi memiliki manfaat antara lain : dapat memulai hidup yang baik, mengandung antibodi, memberikan rasa aman dan nyaman pada bayi, ikatan ibu dan bayi, mencegah bayi dari alergi, meningkatkan kecerdasan bayi. Sedangkan manfaat bagi ibu yaitu dapat mencegah terjadinya kehamilan seperti kontrasepsi, penurunan berat badan dan lain-lain, untuk memperlancar ASI, ibu hamil dan menyusui harus memahami pentingnya perawatan payudara, manfaat ASI. Manajemen laktasi merupakan upaya yang dilakukan untuk mencapai keberhasilan dalam pemberian ASI pada bayi. Teknik pemberian ASI adalah pemberian ASI pada bayi dengan pelekatan dan posisi ibu dan bayi yang tepat, salah satu tujuan pemberian ASI adalah untuk merangsang produksi ASI dan memperkuat refleks isap bayi, dari hasil peninjauan Kegiatan promosi kesehatan ibu hamil dan nifas di Kelurahan Bajur sebagian ibu hamil dan ibu menyusui belum memahami tentang ASI Eksklusif, cara merawat payudara dan teknik menyusui. Saran masyarakat agar lebih sering mengadakan promosi kesehatan seperti ini agar pemberian ASI untuk setiap bayi terpenuhi secara maksimal sehingga menjadi harapan bagi generasi bangsa untuk tumbuh sehat, cerdas dan produktif.

Metode promosi kesehatan dengan teknik seperti ini sangat efektif, dengan metode seperti ini masyarakat dari yang tidak tahu menjadi tahu, karena sebelum kita melakukan promosi kesehatan ini kita melakukan pre tes dan setelah selesai melakukan kita melakukan post tes. Dari metode ini kita bisa mengevaluasi sejauh mana pemahaman peserta sebelum dan setelah kegiatan ini.

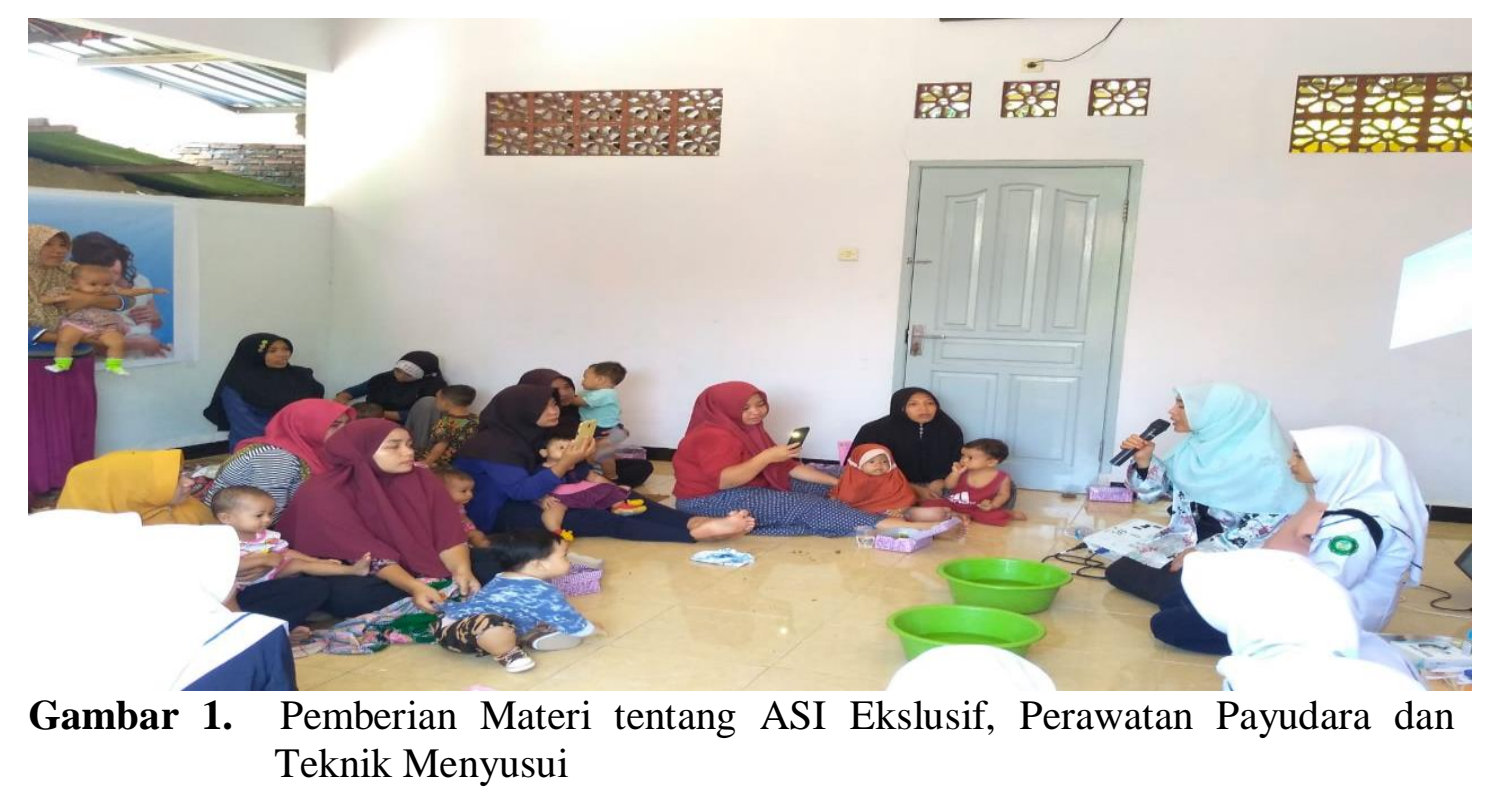




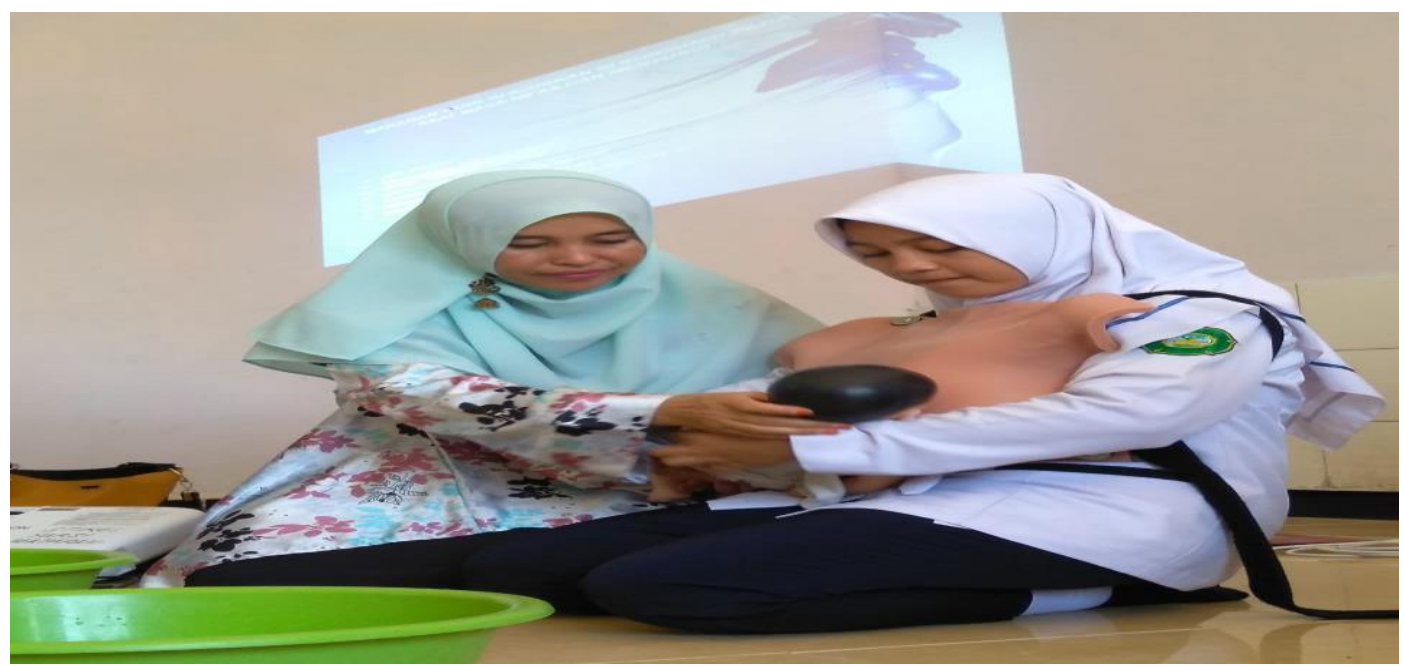

Gambar 2. Demontrasi Teknik Menyusui

\section{KESIMPULAN DAN SARAN}

\subsection{KESIMPULAN}

Perawatan payudara yang dilakukan secara teratur meningkatan dan mencegah payudara lecet saat menyusui. Teknik menyusui yang salah akan mempengaruhi bentuk payudara. Secara fisiologis, perawatan payudara akan mempengaruhi hipofisis untuk melepaskan hormon prolaktin dan oksitosin dengan cara merangsang kelenjar susu melalui massage (Ambarwati and Wulandari D, 2010)

Menurut (Rustam, Mahkota and Kodim, 2019) dari hari 3 hingga ke 6 setelah persalinan, payudara akan terasa penuh yang merupakan kondisi normal. Fisiologisya dengan inhalasi dan ekskresi ASI yang efektif oleh bayi, kepenuhan dengan cepat dipulihkan. Namun, bisa berkembang menjadi bendungan. Payudara sangat penuh dengan susu dan cairan jaringan. Aliran pembuluh darah limfatik terhambat, aliran susu menjadi terhambat dan tekanan pada saluran susu dan alveoli meningkat dengan cara merangsang kelenjar susu melalui pemijatan. Gerakan dalam perawatan payudara berguna untuk melancarkan refleks menyusui. Ini juga merupakan cara yang efektif untuk meningkatkan volume payudara dan mencegah kerusakan pada payudara (Sofian, 2011).

\subsection{SARAN}

Program layanan ini diharapkan dapat dilaksanakan secara berkelanjutan dalam meningkatkan cakupan ASI Eksklusif yang menjadi sasaran pemerintah. Diharapkan para tokoh masyarakat dan aparat desa lebih giat melakukan penyuluhan serupa dengan melibatkan pihak-pihak yang terkait, diharapkan orang Indonesia bisa punya keturunan yang sehat, kuat dan produktif.

\section{UCAPAN TERIMA KASIH}

Ucapan terimakasih yang sebesar-besarnya kami sampaikan kepada ibu hamil dan ibu nifas yang telah mengikuti kegiatan edukasi ini serta aparat dusun dan desa di wilayah Desa Bajur, Kecamatan Labuapi, Kota Mataram, Nusa Tenggara Barat 
yang telah mendukung dan mencanangkan acara tersebut. Semoga acara promosi kesehatan ini bermanfaat dan dapat berkelanjutan.

\section{DAFTAR RUJUKAN}

Aarts, C. et al. (2000). How Exclusive Is Exclusive Breastfeeding? A comparison Of Data Since Birth With Current Status Data, International Journal of epidemiology, 29(6), pp. 1041-1046.

Agustina, R. R. (2014). Hubungan Antara Pelaksanaan Inisiasi Menyusu Dini (IMD) Dengan Pemberian Asi Eksklusif 6 Bulan Pada Wanita Primipara Di Indonesia Tahun 2012: Analisis Survei Demografi Kesehatan Indonesia tahun 2012= Relationship of breast crawl and exclusive breastfeedin.

Ambarwati, E. R. and Wulandari D. (2010). Wulandari D, Asuhan Kebidanan Masa Nifas. Yogyakarta: Nuha Medika.

Chung, W., Kim, H. and Nam, C.-M. (2008). Breast-feeding in South Korea: factors influencing its initiation and duration, Public health nutrition, 11(3), pp. 225229.

Depkes, R, I. (2001). Buku Panduan Manajemen Laktasi. Jakarta: Dit. Gizi Masyarakat-Depkes RI.

Dewan, N. et al. (2002). Breast-feeding knowledge and attitudes of teenage mothers in Liverpool. Journal of Human Nutrition and Dietetics, 15(1), pp. 33-37.

Haryono, R. and Setianingsih, S. (2014). Manfaat ASI eksklusif untuk buah hati anda, Yogyakarta: Gosyen Publishing, pp. 1-30.

Kristiyansari, W. (2009). ASI, Menyusui dan Sadari, Yogyakarta: Nuha Medika, pp. $18-67$.

Mulianingsih, M., Nurmayani, W. and Rusiana, H. P. (2016). The Effectivity Of Breastfeeding Technique Education Related To Onset Of Lactation Of Caesarean Section-Delivered Mother In Mataram City General Hospital. Indonesian Nursing Journal Of Education And Clinic (Injec), 1(1), pp. 75-81.

Mulyani, N. S. (2013). Asi dan pedoman ibu menyusui. Nuha Medika. Yogyakarta.

Rustam, M., Mahkota, R. and Kodim, N. (2019). Exclusive Breastfeeding and Decrease of Upper respiratory Infection Incidence among Infants Aged 6-12 Months in Kampar District, Riau Province. Kesmas: National Public Health Journal, 13(3), pp. 117-123. 
164 Jurnal Empathy, Volume 1, No 2, Desember 2020, hlm 96-

Sofian, A. (2011). Sinopsis Obstetri: Obstetri Operatif, Obstetri Sosial. Jakarta: $E G C$.

WHO (2011). Pelatihan konseling menyusui modul 40 jam WHO/UNICEF. WHO/UNICEF.

Yanikkerem, E. et al. (2009). Breast-feeding knowledge and practices among mothers in Manisa, Turkey. Midwifery, 25(6), pp. e19-e32. 